\title{
elsevier_SSM_9854
}

\section{Resistance and mutations of non-specificity in the field of anxiety-depressive disorders in Canadian medical journals, 1950-1990}

Johanne Collin **

Johanne.collin@umontreal.ca

Marcelo Otero

asociology and History of Health Sciences. Faculty of Pharmacy. Research Group on Medications as social objects (MEOS). University of Montreal, Canada

bepartment of Sociology, University of Quebec at Montreal (UQAM), Canada

*Corresponding author. University of Montreal, 2940 chemin de Polytechnique, bureau 2250, Montréal, Québec H3T 1J4, Canada.

\section{Abstract}

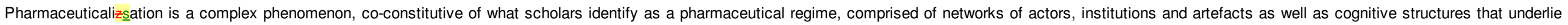

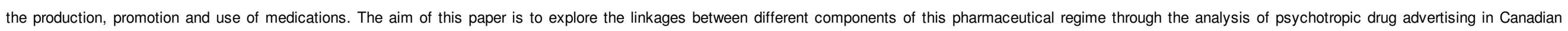

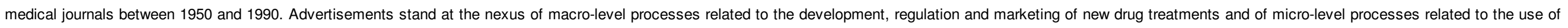

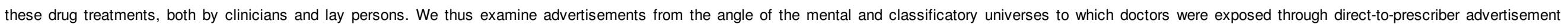

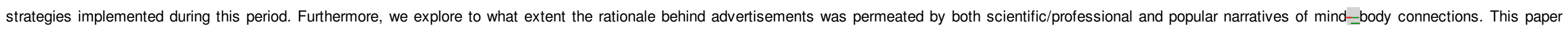

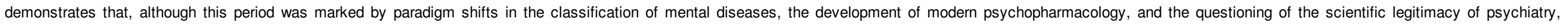

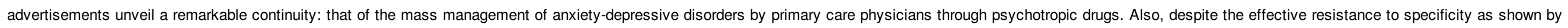

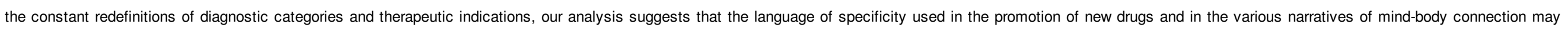

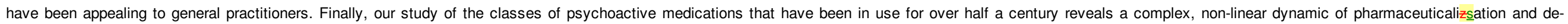
pharmaceuticalizsation.

Keywords: Psychotropic drugs; Advertising; Primary care; Pharmaceuticalisation; Anxiety; Depression; Modern psychopharmacology; Specificity

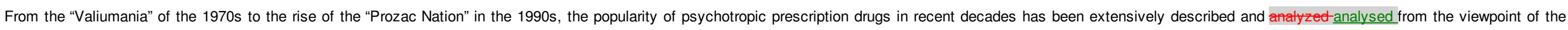

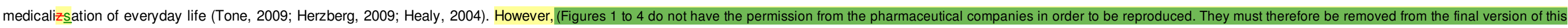

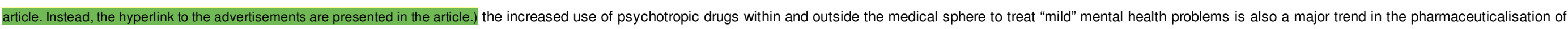

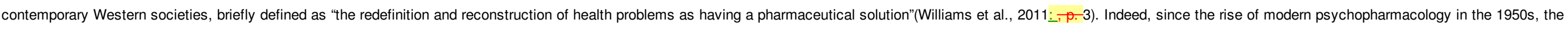

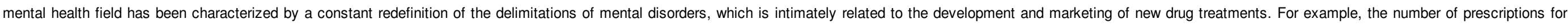

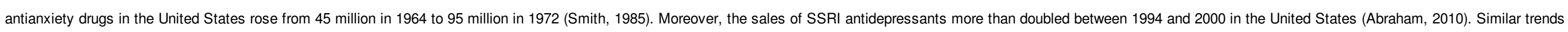
have been reported in Canada and Europe.

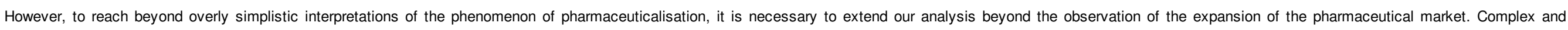

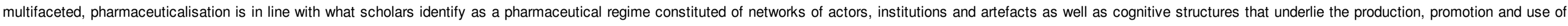
medications (Williams et al., 2011). We define cognitive structures as culturally and socially accepted coding systems or classifications.

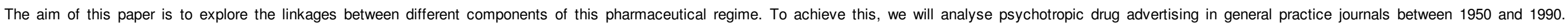

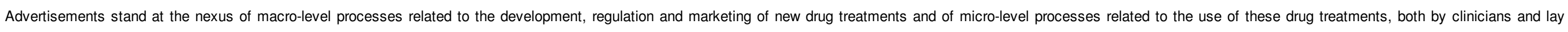




\section{elsevier_SSM_9854}

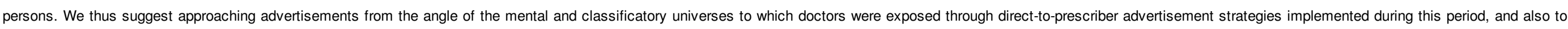
explore to what extent the rationale behind advertisements is permeated by both scientific/professional and popular narratives of mind--body connections.

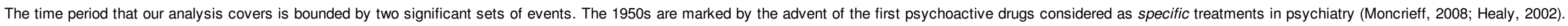

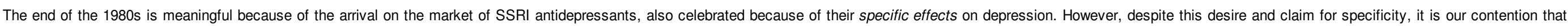

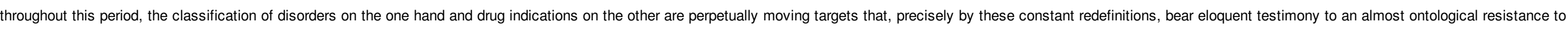
the paradigm of specificity.

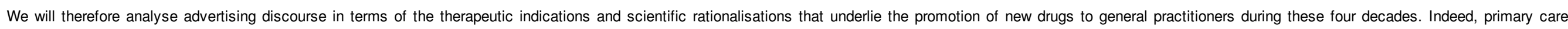

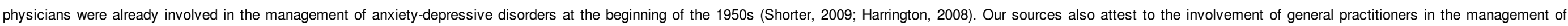
emotional tensions, anxiety and depression in Canada from the 1950s and 1960s, and to the desire on their part for more training regarding these disorders (Fortin, 1965).

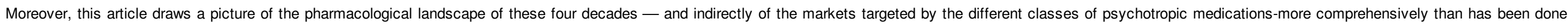

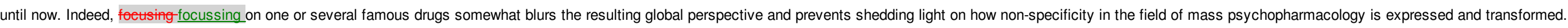

\section{The issue of contemporary anxiety-depressive disorders}

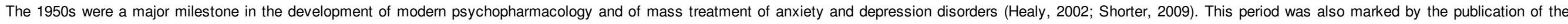

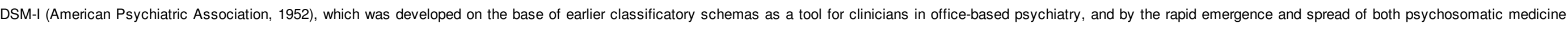
and the concept of stress (Harrington, 2008; Viner, 1999).

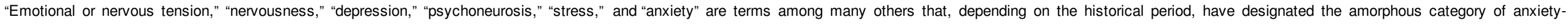

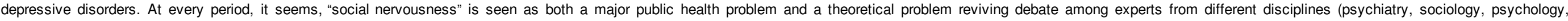

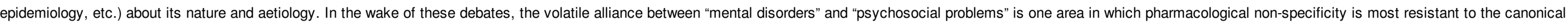
model of "one drug, one disease".

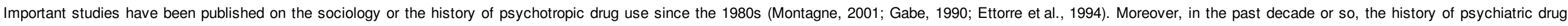

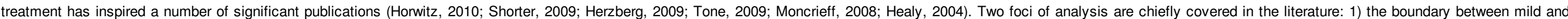

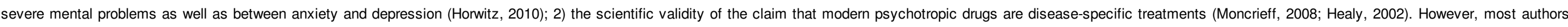

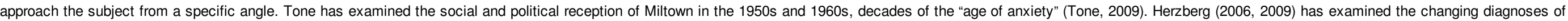

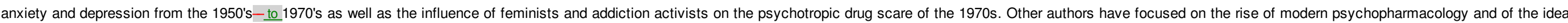

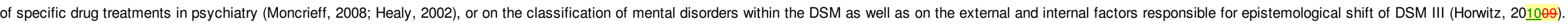

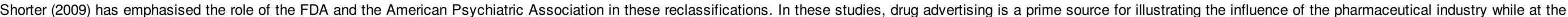
same time accounting for everyday clinical practice in the field.

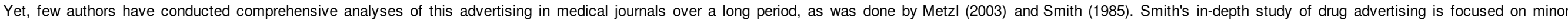

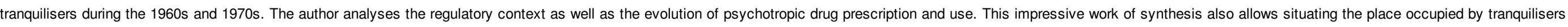

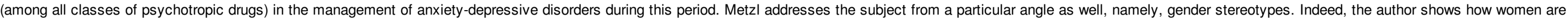

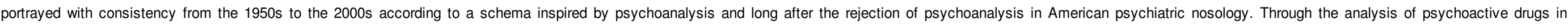
psychiatric journals, Metzl's thesis demonstrates how drug treatments have replaced therapy in the management of neuroses.

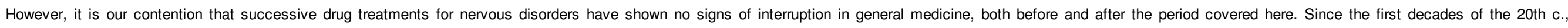

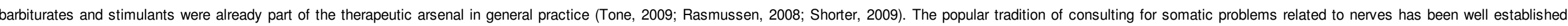

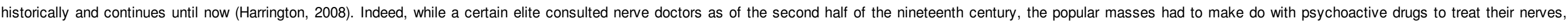




\section{elsevier_SSM_9854}

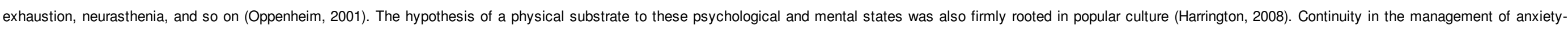

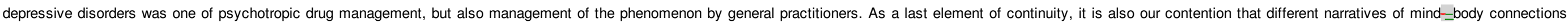

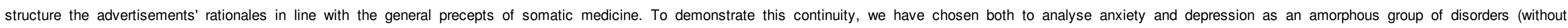
foeusing focussing on one or the other pole) and to consider the pharmacological landscape as a whole (without fousing focussing on one or another class of psychotropic drugs).

\section{Method}

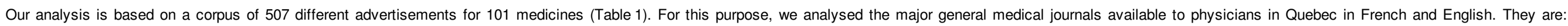

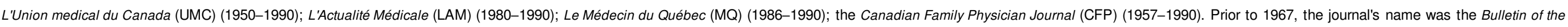

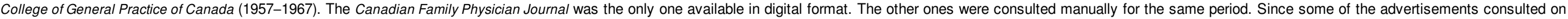

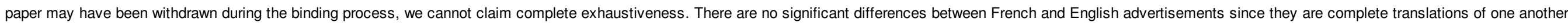

Table 1 List of drugs by decade and by class (first appearance in medical journals).

\begin{tabular}{|c|c|c|c|c|c|c|}
\hline & Barbiturates & Antipsychotics & Stimulants & Nonbarbiturate hypnotics & Antidepressants & Nonbarbiturate sedatives and anxiolytics \\
\hline \multirow[t]{12}{*}{$1950-59$} & Vago-frena 1951 & Sparine 1956 & Dexedrine 1951 & Somnos 1952 & & Equanil 1959 \\
\hline & Seconal sodique 1952 & Pacatal 1956 & Theptine 1952 & Doriden 1955 & & \\
\hline & Neurotrasantine 1953 & Largactil 1957 & Plimasine 1954 & Pééritrate 1958 & & \\
\hline & Soneéril Sonalgin 1953 & Phenergan 1957 & Benzedrine 1955 & & & Atarax 1960 \\
\hline & Trasentol 1953 & Stemetil 1957 & Dexamyl 1956 & & & tibrium 1964 \\
\hline & Seco-trazole 1955 & Trilafon 1957 & & & & tibrax 1962 \\
\hline & Medomine 1956 & Larga-dex 1958 & & & & Sérax 1965 \\
\hline & Neurocentrine 1956 & Equazine 1959 & & & & Valium 1965 \\
\hline & Veratrite 1956 & Nozinan 1959 & & & & Naek 1967 \\
\hline & Eskabarb 1957 & Stelazine 1959 & & & & Protensin 1968 \\
\hline & Dartal 1958 & & & & & Pentrium 1969 \\
\hline & Restropin 1959 & & & & & \\
\hline \multirow[t]{10}{*}{$1960-69$} & Plexonal 1961 & Mellaril 1960 & Eskatrol 1960 & Meéquelon 1962 & Nardil 1960 & $\underline{\text { Atarax } 1960}$ \\
\hline & Nuambutal 1963 & Permitil 1960 & Tenuate 1965 & Placydil 1966 & Tofranil 1960 & Librium 1961 \\
\hline & Carbitral 1964 & Sparidol 1962 & Biphetamine 1967 & Noludar 1968 & Elavil 1961 & Librax 1962 \\
\hline & Donnatal 1964 & Amylozine Spansule 1963 & Ionamin 1967 & Tualone 1969 & Monase 1962 & $\underline{\text { Serax } 1965}$ \\
\hline & Donnazyme 1964 & Moditen 1963 & Ritalin 1967 & & Parstelin 1962 & $\underline{\text { Valium } 1965}$ \\
\hline & Soneéryl 1964 & Steélabid 1963 & Preéludine 1968 & & Etrafon 1965 & Nack 1967 \\
\hline & Meédomine 1965 & Haldol 1967 & & & Pertrofan 1965 & Protensin 1968 \\
\hline & Pro-banthine 1965 & Neuleptil 1969 & & & Surmontil 1965 & Pentrium 1969 \\
\hline & Bellergal 1966 & & & & Triavil 1965 & \\
\hline & Solacen 1966 & & & & Aventyl 1966 & \\
\hline
\end{tabular}




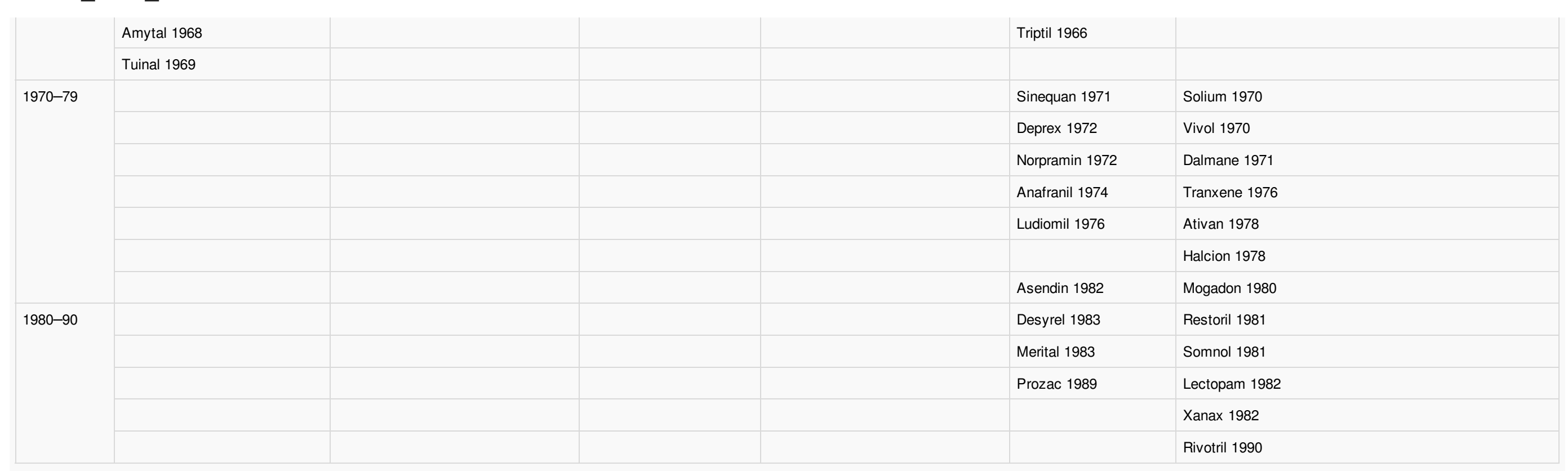

We conducted content analysis of primary and secondary messages of the various advertisements by forsing focussing on the primary indications for which the drugs were promoted. For each advertisement, we used the following information: brand name, active ingredients, image shown, main message, secondary message, indications contained in the advertisement, references to other products, scientific references, month and year of the first appearance of the advertisement. No duplicate advertisements were included in the present study. Only the first appearance of an advertisement was used, but several different advertisements for the same drug are part of our sample.

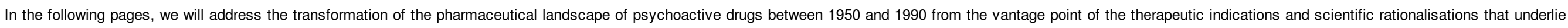

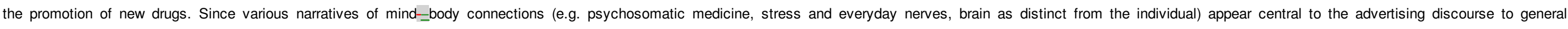

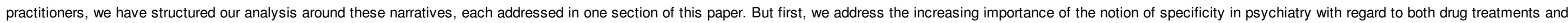
the classification of mental disorders.

\section{Specific drugs and specific diagnoses}

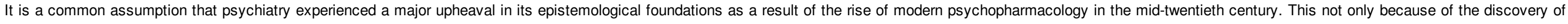

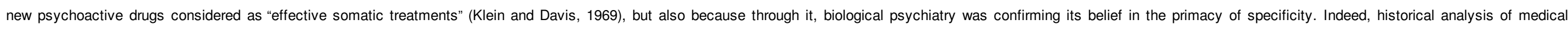

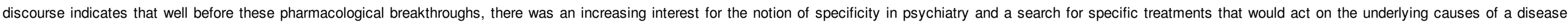

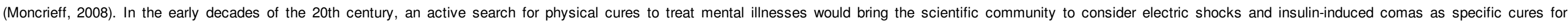
schizophrenia and endogenous depression respectively, before the discovery of chlorpromazine and imipramine (Braslow, 1997). According to Moncrieff (2008):

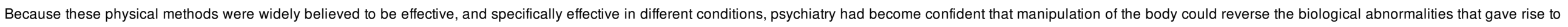
mental disorders. The new drugs were the natural inheritors of these beliefs (p. 45).

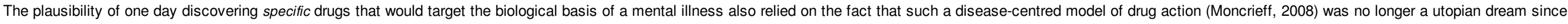
the discovery of sulphonamides in bacteriology and of insulin in endocrinology (Rosenberg, 2007; Pellegrino, 1979).

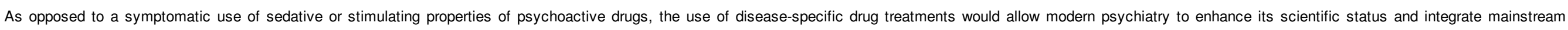
American medicine through its commitment to the doctrine of specificity (Pellegrino, 1979). Nonetheless, there was a need to link specific drug treatments to specific diseases. 


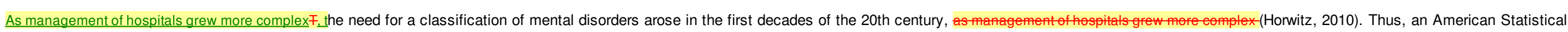
Manual for the Use of Hospitals for Mental Disorders (1918) was published in 1918 and more importantly, a list of mental disorders was added to the International Classification of Diseases in 1938. However, according to the authors of DSM-I

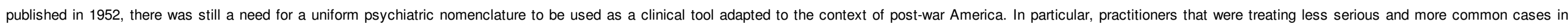

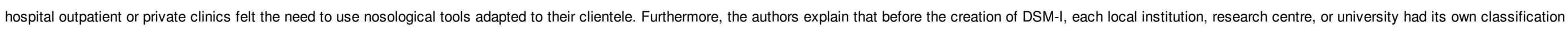

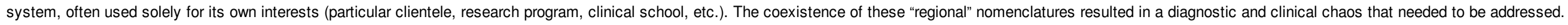

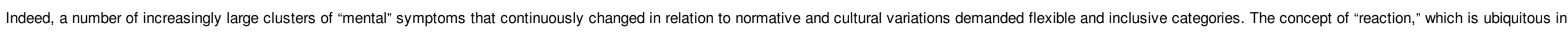

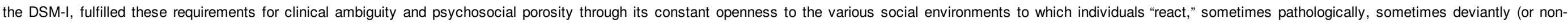

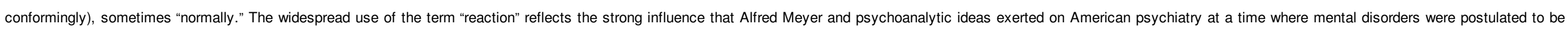
reactions of the patient's personality to psychological, social and biological factors.

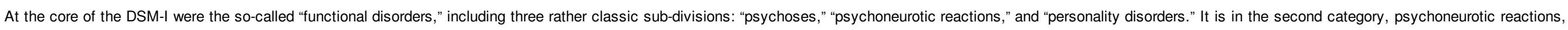

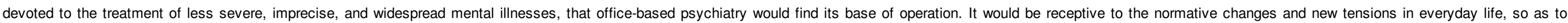

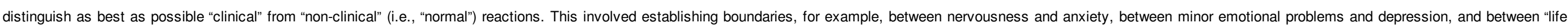

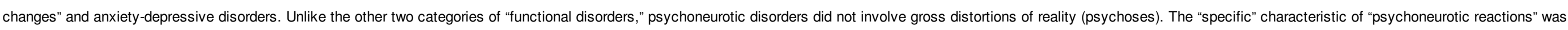

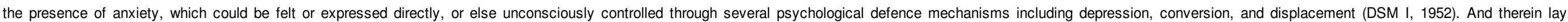
depression during this period.

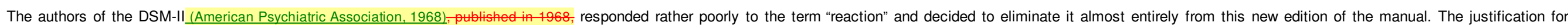

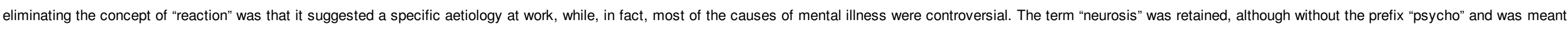

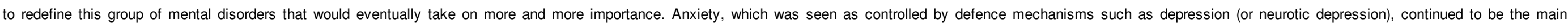

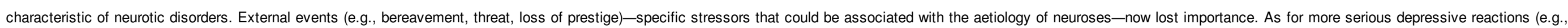
emotional reaction, manic-depressive reaction, psychotic depressive reaction, involutional melancholia), they still belonged to separate group of qualitatively different disorders: psychoses.

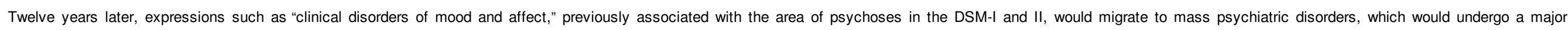

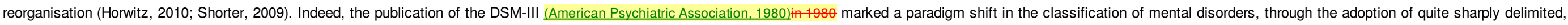

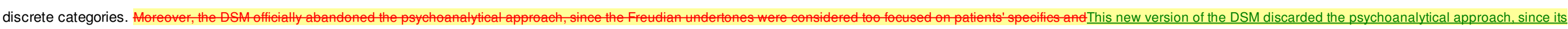

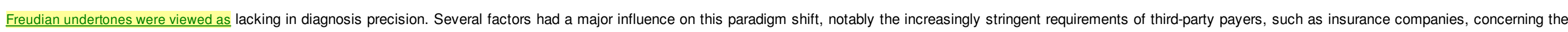

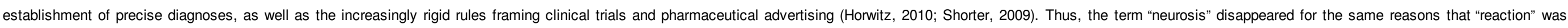

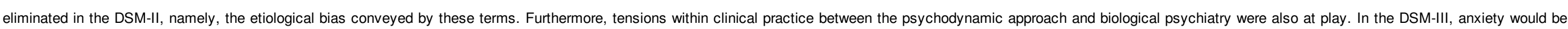

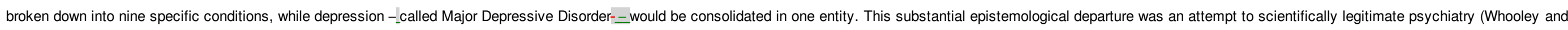
Horwitz, 2013).

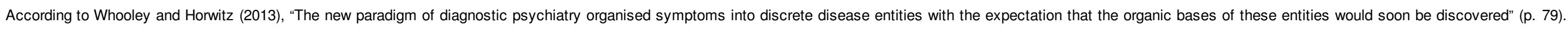

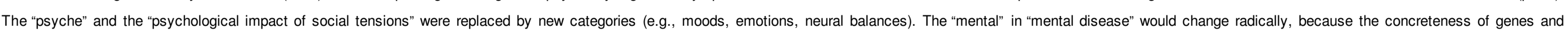

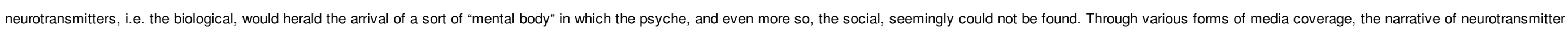
would permeate popular culture (Montagne, 2001).

While the nosology and aetiology underlying the psychopathology of everyday life would change with successive editions of the DSM, what do we know about drug advertising aimed at general practitioners?

\section{Transformation of the pharmaceutical landscape from the 1950 s to $1990 \mathrm{~s}$}

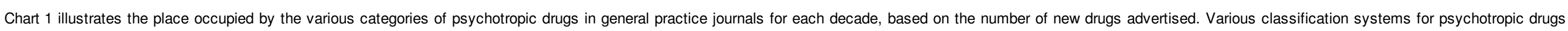




\section{elsevier_SSM_9854}

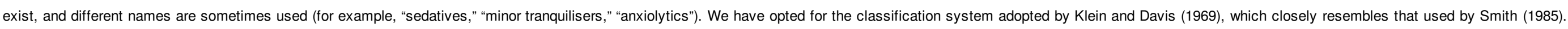

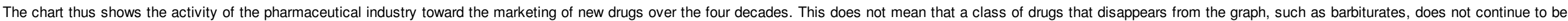

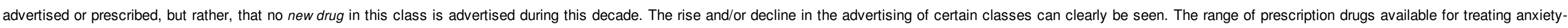
depressive disorders in the 1950s is radically different from that of the 1980s and serves to show, as we will discuss further, a complex and non-linear process of pharmaceuticalisation/de-pharmaceuticalisation.

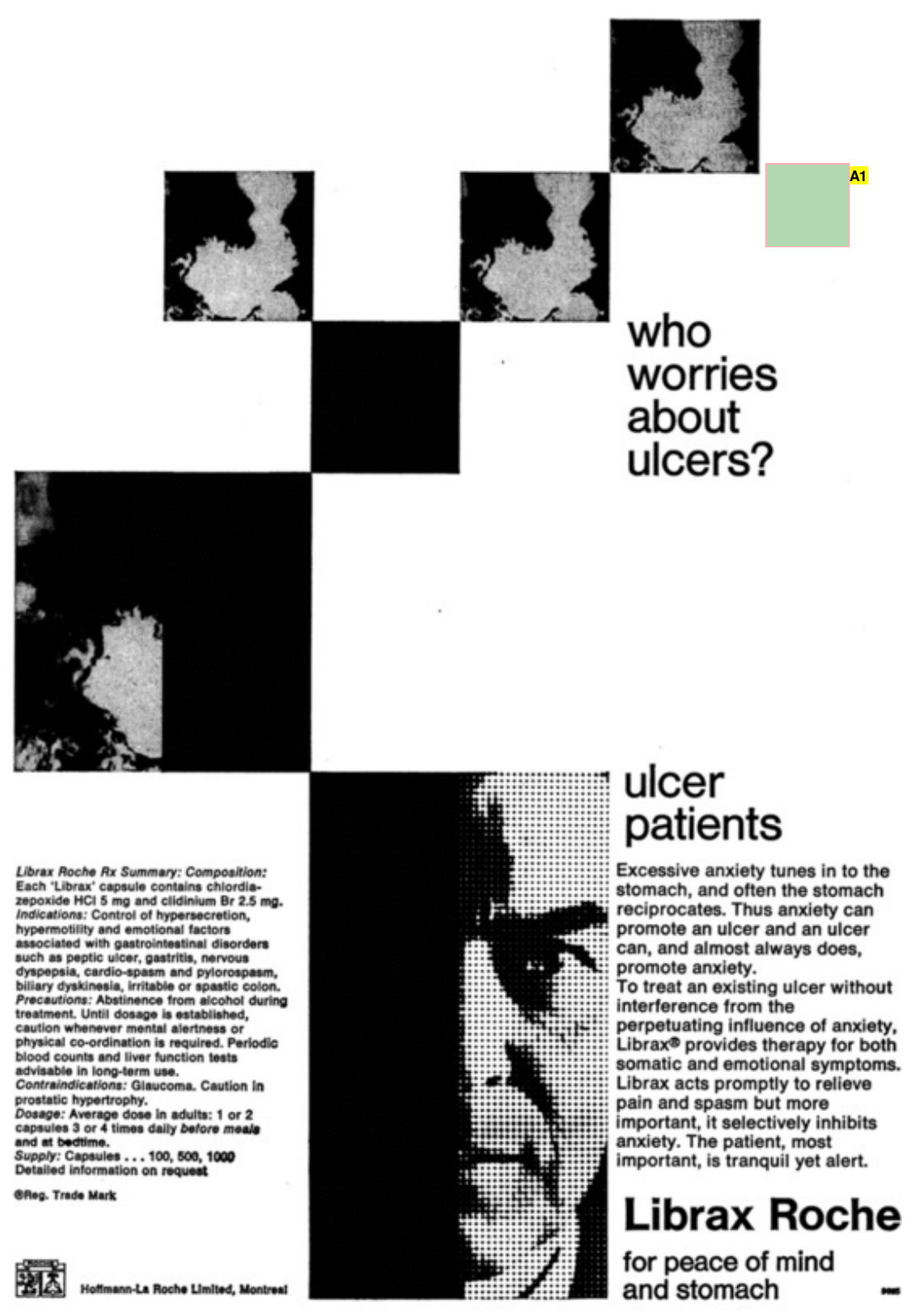

CANADIAN FAMUIY PHYSICAN - APRLL, 1970

Fig. 1 Canadian Family Physician, April 1970 
Annotations:

A1. figures 1 to 4 do not have the permission from the pharmaceutical companies in order to be reproduced. They must therefore be removed from the final version of this article

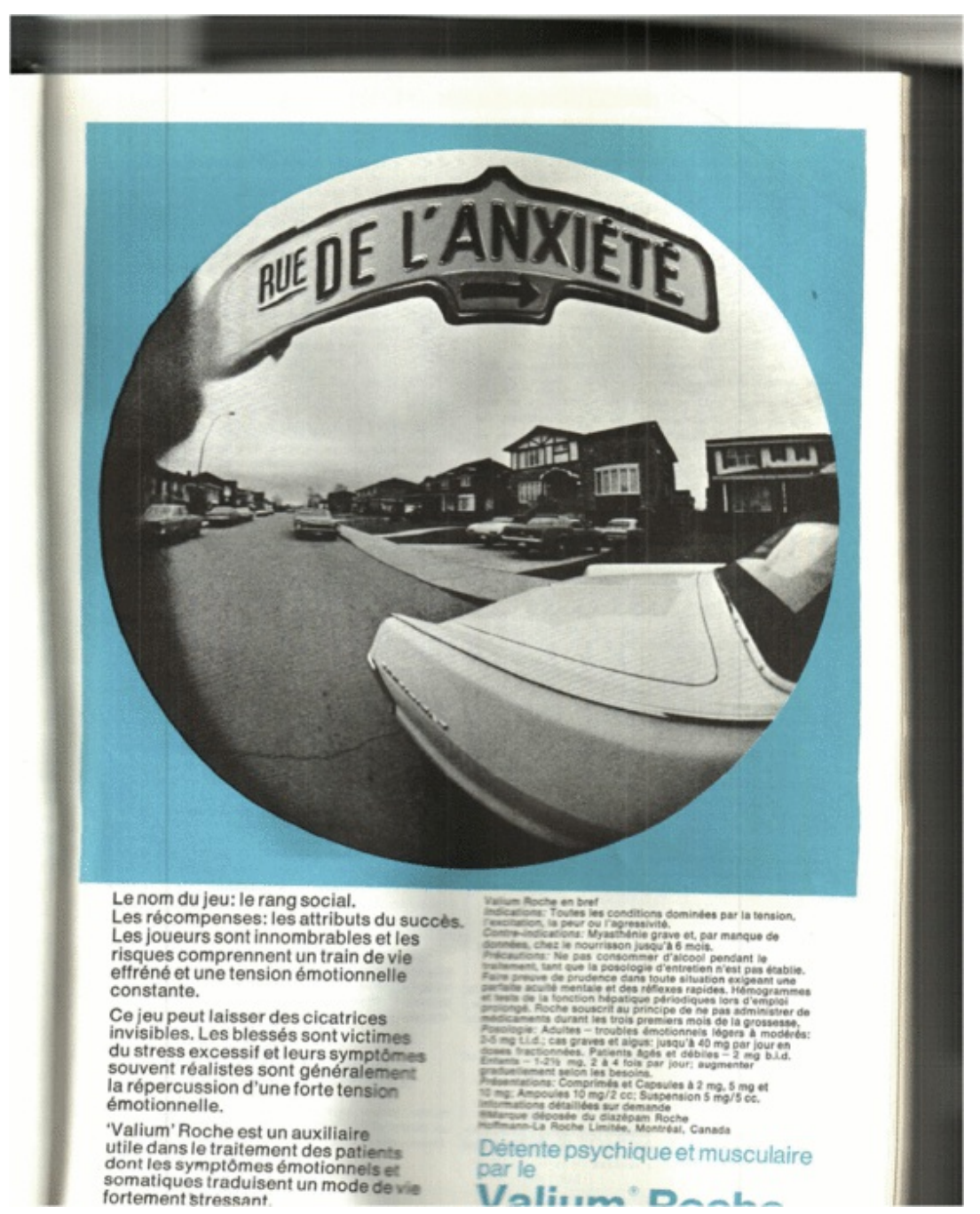

Fig. 2 Union Médical du Canada, May 1965. 


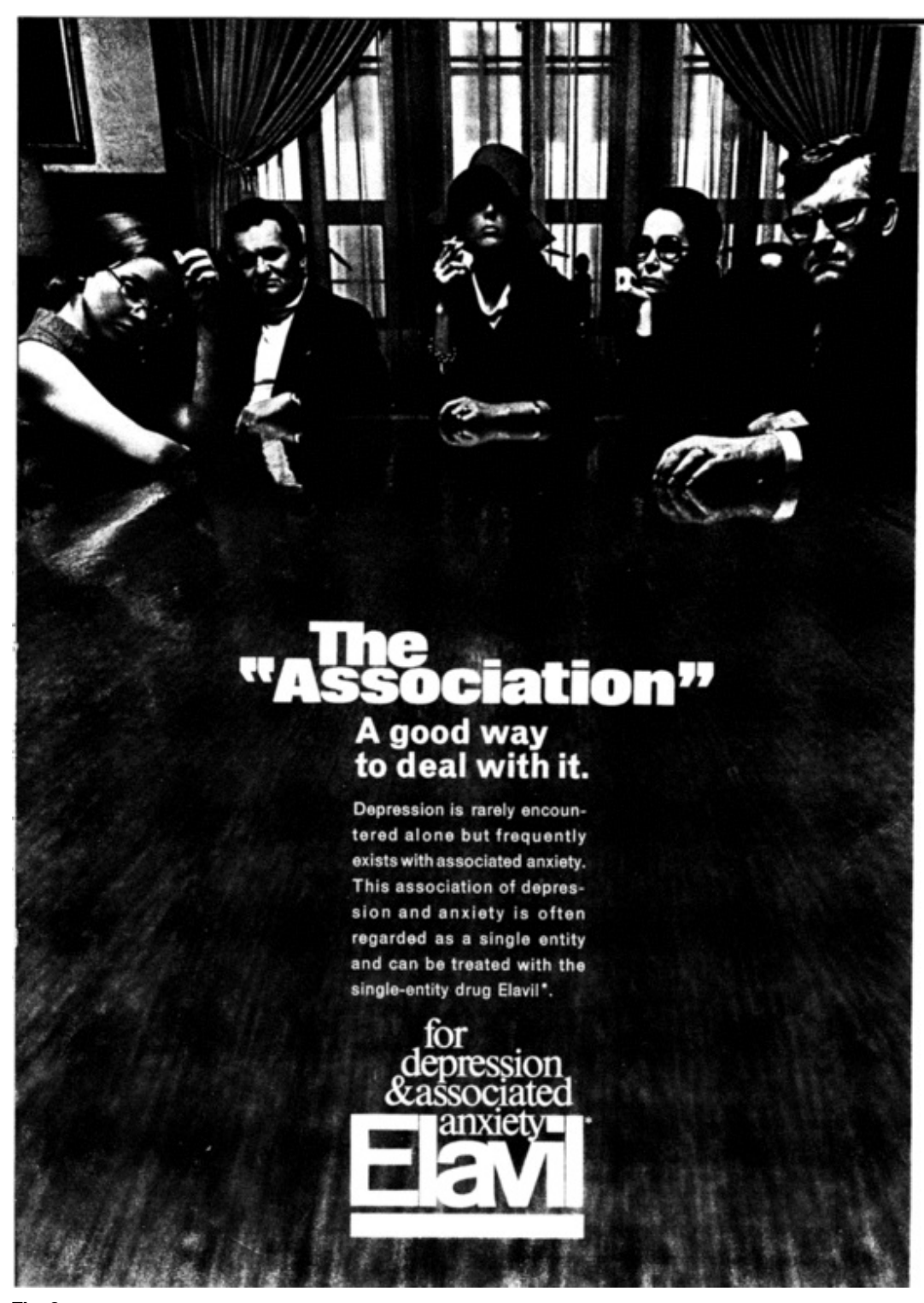

Fig. 3 Canadian Physician Family Journal, December 1975. 


\section{ENONDES}

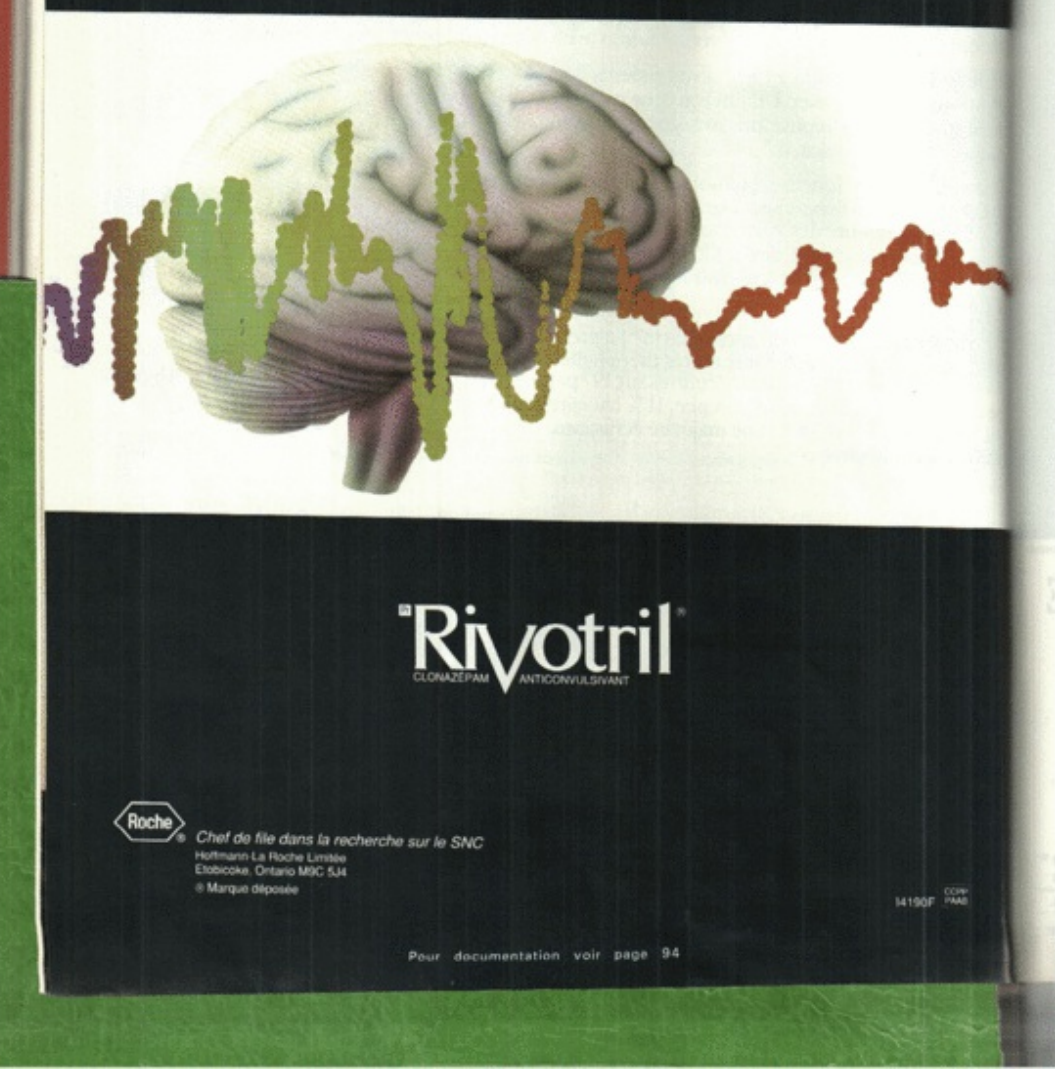

Fig. 4 Le Médecin du Québec, August 1990. 


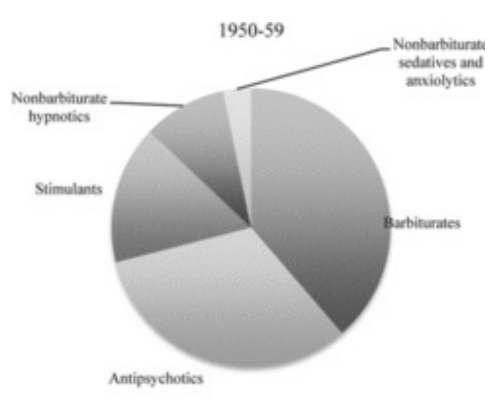

$1970-79$

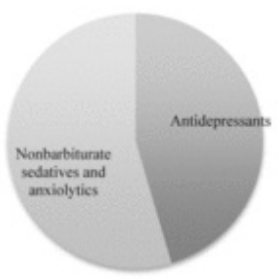

$1960-69$

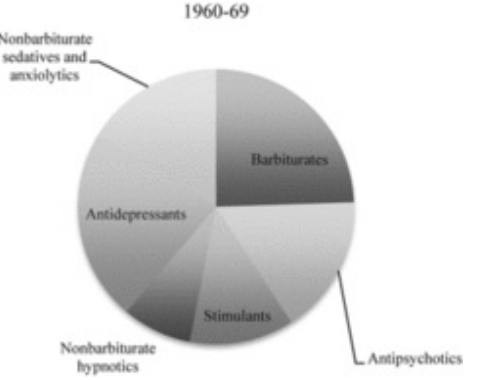

$1980-90$

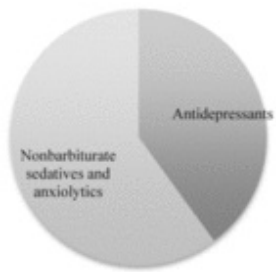

Chart 1 Evolution of the categories of drugs advertised by decade, based on the number of new drugs advertised.

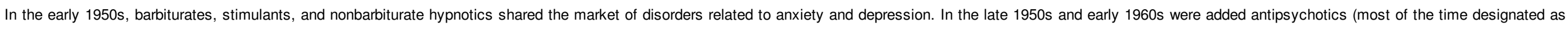

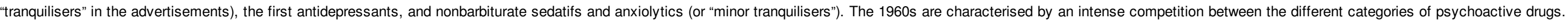
Finally, the 1970s and 1980s are characterised by the almost complete disappearance of classes other than anxiolytics and antidepressants.

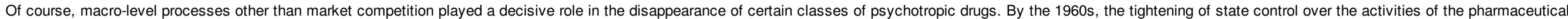

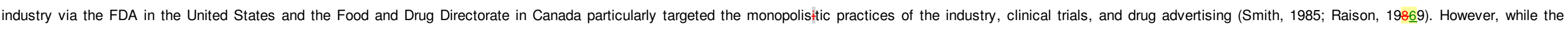

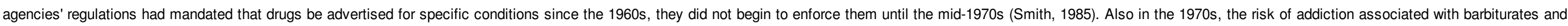

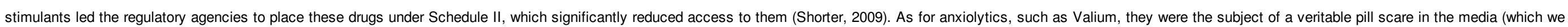
address further on) (Herzberg, 2009).

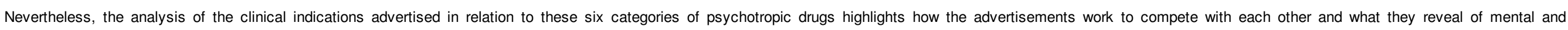

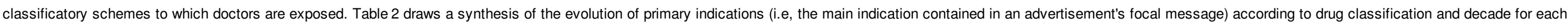

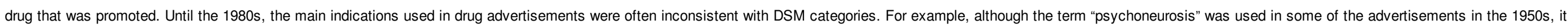

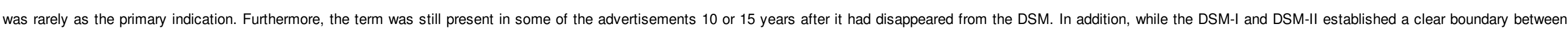
psychotic and neurotic depression, several antidepressants, since the 1960's, were marketed as a treatment for the entire spectrum of depressive disorders.

Table 2 Evolution of the primary indication, by class and by decade.

\begin{tabular}{|c|c|c|c|c|c|c|c|c|c|c|c|c|}
\hline & & $\begin{array}{c}\text { Mental } \\
\text { disorders }\end{array}$ & Anxiety & Depression & $\begin{array}{l}\text { Anxiety and } \\
\text { depression }\end{array}$ & $\begin{array}{l}\text { Emotional or nervous } \\
\text { tension }\end{array}$ & $\begin{array}{l}\text { Psychosomatic } \\
\text { disease }\end{array}$ & Insomnia & $\begin{array}{l}\text { Chronic } \\
\text { fatigue }\end{array}$ & $\begin{array}{l}\text { Obesity, } \\
\text { overweight }\end{array}$ & Miscellaneous & Total \\
\hline \multirow[t]{3}{*}{ Barbiturates } & 1950-1959 & $0 \%$ & $5 \%$ & $0 \%$ & $0 \%$ & $26 \%$ & $47 \%$ & $21 \%$ & $0 \%$ & $0 \%$ & $0 \%$ & $100 \%$ \\
\hline & 1960-1969 & $0 \%$ & $0 \%$ & $0 \%$ & $0 \%$ & $26 \%$ & $49 \%$ & $26 \%$ & $0 \%$ & $0 \%$ & $0 \%$ & $100 \%$ \\
\hline & 1970-1979 & $0 \%$ & $0 \%$ & $0 \%$ & $0 \%$ & $22 \%$ & $33 \%$ & $33 \%$ & $0 \%$ & $0 \%$ & $11 \%$ & $100 \%$ \\
\hline
\end{tabular}




\begin{tabular}{|c|c|c|c|c|c|c|c|c|c|c|c|c|}
\hline & $1980-1990$ & $0 \%$ & $0 \%$ & $0 \%$ & $0 \%$ & $0 \%$ & $100 \%$ & $0 \%$ & $0 \%$ & $0 \%$ & $0 \%$ & $100 \%$ \\
\hline \multirow{4}{*}{$\begin{array}{l}\text { Nonbarbiturate sedatives and } \\
\text { anxiolytics }\end{array}$} & 1950-1959 & $0 \%$ & $0 \%$ & $0 \%$ & $0 \%$ & $0 \%$ & $0 \%$ & $0 \%$ & $0 \%$ & $0 \%$ & $0 \%$ & $100 \%$ \\
\hline & 1960-1969 & $0 \%$ & $42 \%$ & $0 \%$ & $0 \%$ & $27 \%$ & $31 \%$ & $0 \%$ & $0 \%$ & $0 \%$ & $0 \%$ & $100 \%$ \\
\hline & 1970-1979 & $0 \%$ & $32 \%$ & $0 \%$ & $0 \%$ & $14 \%$ & $18 \%$ & $26 \%$ & $0 \%$ & $0 \%$ & $10 \%$ & $100 \%$ \\
\hline & 1980-1990 & $0 \%$ & $60 \%$ & $0 \%$ & $0 \%$ & $0 \%$ & $5 \%$ & $34 \%$ & $0 \%$ & $0 \%$ & $0 \%$ & $100 \%$ \\
\hline \multirow[t]{4}{*}{ Antidepressants } & 1950-1959 & $0 \%$ & $0 \%$ & $0 \%$ & $0 \%$ & $0 \%$ & $0 \%$ & $0 \%$ & $0 \%$ & $0 \%$ & $0 \%$ & $100 \%$ \\
\hline & 1960-1969 & $0 \%$ & $0 \%$ & $50 \%$ & $43 \%$ & $8 \%$ & $0 \%$ & $0 \%$ & $0 \%$ & $0 \%$ & $0 \%$ & $100 \%$ \\
\hline & 1970-1979 & $0 \%$ & $0 \%$ & $53 \%$ & $41 \%$ & $0 \%$ & $0 \%$ & $0 \%$ & $0 \%$ & $0 \%$ & $6 \%$ & $100 \%$ \\
\hline & 1980-1990 & $0 \%$ & $0 \%$ & $98 \%$ & $2 \%$ & $0 \%$ & $0 \%$ & $0 \%$ & $0 \%$ & $0 \%$ & $0 \%$ & $100 \%$ \\
\hline \multirow[t]{4}{*}{ Antipsychotics } & 1950-1959 & $36 \%$ & $32 \%$ & $5 \%$ & $5 \%$ & $9 \%$ & $9 \%$ & $0 \%$ & $0 \%$ & $0 \%$ & $5 \%$ & $100 \%$ \\
\hline & 1960-1969 & $32 \%$ & $36 \%$ & $0 \%$ & $2 \%$ & $7 \%$ & $2 \%$ & $2 \%$ & $0 \%$ & $0 \%$ & $18 \%$ & $100 \%$ \\
\hline & 1970-1979 & $18 \%$ & $18 \%$ & $0 \%$ & $12 \%$ & $0 \%$ & $29 \%$ & $0 \%$ & $0 \%$ & $0 \%$ & $24 \%$ & $100 \%$ \\
\hline & 1980-1990 & $0 \%$ & $0 \%$ & $0 \%$ & $0 \%$ & $33 \%$ & $33 \%$ & $0 \%$ & $0 \%$ & $0 \%$ & $33 \%$ & $100 \%$ \\
\hline \multirow[t]{4}{*}{ Stimulants } & 1950-1959 & $0 \%$ & $0 \%$ & $27 \%$ & $7 \%$ & $0 \%$ & $0 \%$ & $0 \%$ & $33 \%$ & $33 \%$ & $0 \%$ & $100 \%$ \\
\hline & 1960-1969 & $0 \%$ & $0 \%$ & $10 \%$ & $0 \%$ & $0 \%$ & $0 \%$ & $0 \%$ & $10 \%$ & $81 \%$ & $0 \%$ & $100 \%$ \\
\hline & 1970-1979 & $0 \%$ & $0 \%$ & $25 \%$ & $0 \%$ & $0 \%$ & $0 \%$ & $0 \%$ & $0 \%$ & $25 \%$ & $50 \%$ & $100 \%$ \\
\hline & 1980-1990 & $0 \%$ & $0 \%$ & $0 \%$ & $0 \%$ & $0 \%$ & $0 \%$ & $0 \%$ & $0 \%$ & $100 \%$ & $0 \%$ & $100 \%$ \\
\hline \multirow[t]{4}{*}{ Nonbarbiturate hypnotics } & 1950-1959 & $0 \%$ & $40 \%$ & $0 \%$ & $0 \%$ & $0 \%$ & $0 \%$ & $60 \%$ & $0 \%$ & $0 \%$ & $0 \%$ & $100 \%$ \\
\hline & 1960-1969 & $0 \%$ & $6 \%$ & $0 \%$ & $0 \%$ & $0 \%$ & $0 \%$ & $88 \%$ & $0 \%$ & $0 \%$ & $6 \%$ & $100 \%$ \\
\hline & 1970-1979 & $0 \%$ & $0 \%$ & $0 \%$ & $0 \%$ & $0 \%$ & $0 \%$ & $100 \%$ & $0 \%$ & $0 \%$ & $0 \%$ & $100 \%$ \\
\hline & 1980-1990 & $0 \%$ & $0 \%$ & $0 \%$ & $0 \%$ & $0 \%$ & $0 \%$ & $100 \%$ & $0 \%$ & $0 \%$ & $0 \%$ & $100 \%$ \\
\hline
\end{tabular}

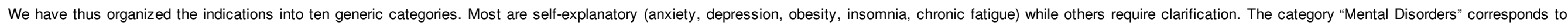

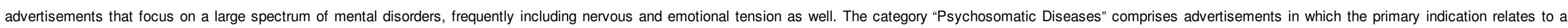
somatic disease (mainly peptic ulcer or other gastrointestinal disorders) that is caused, according to the rationale of the advertisements, by anxiety or nervousness.

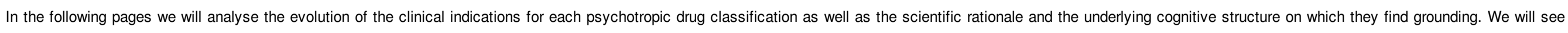

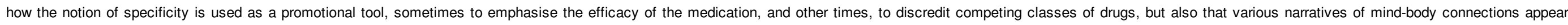
central to the management of anxiety-depressive disorders in general practice.

\section{The rise and fall of "famous" classes of psychoactive drugs and the primacy of psychosomatic medicine}

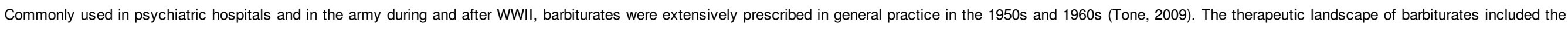

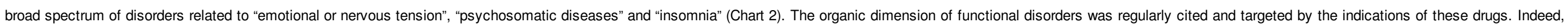

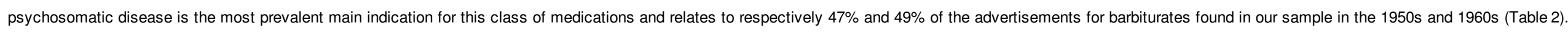




\section{elsevier_SSM_9854}
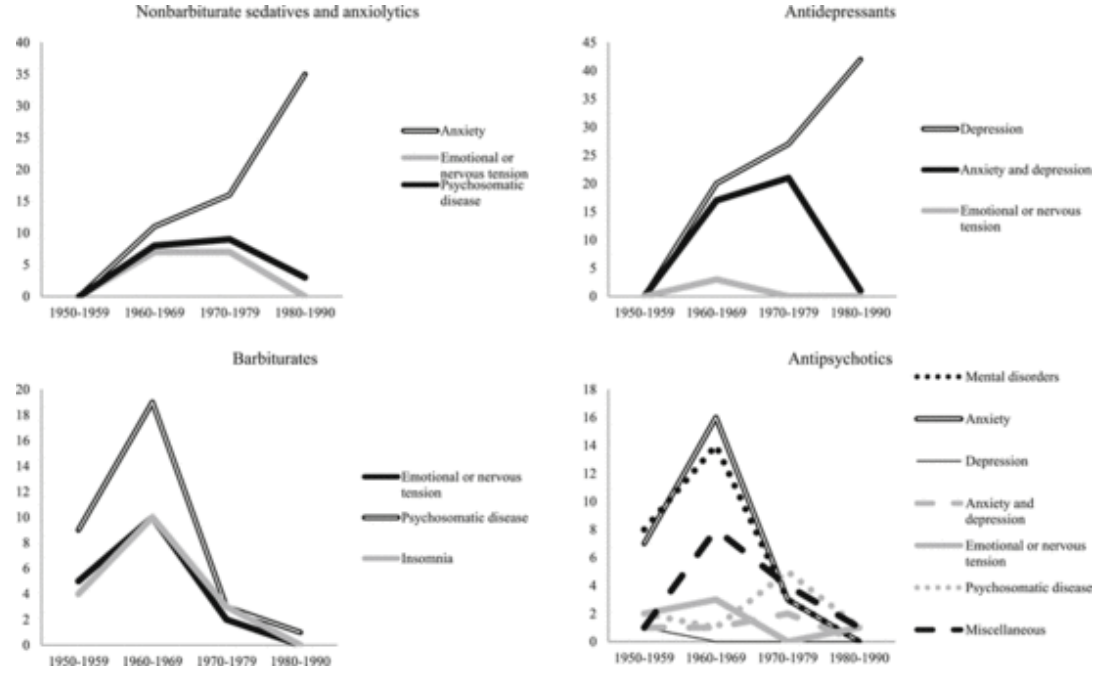

Chart 2 Evolution of the primary indication by decade for 4 drug categories

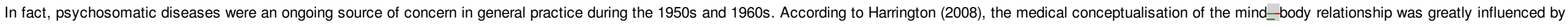

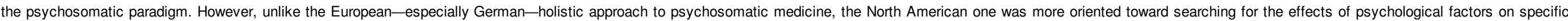

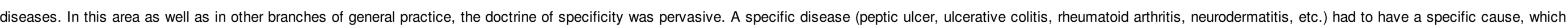

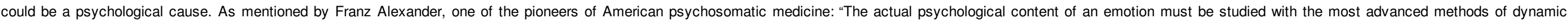

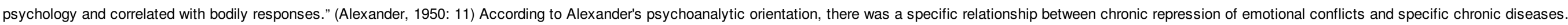

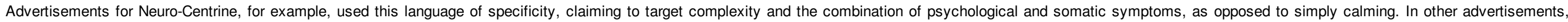

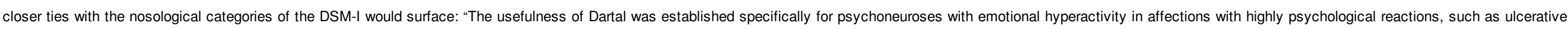
colitis, gastric ulcers, and certain senile psychoses"(Dartal, UMC, June 1958). However, all references to DSM categories disappear from barbiturate advertisements in the 1960's.

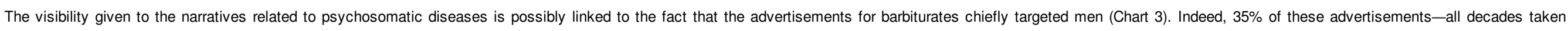

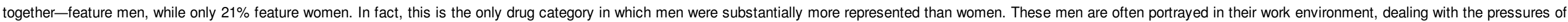
the workplace.

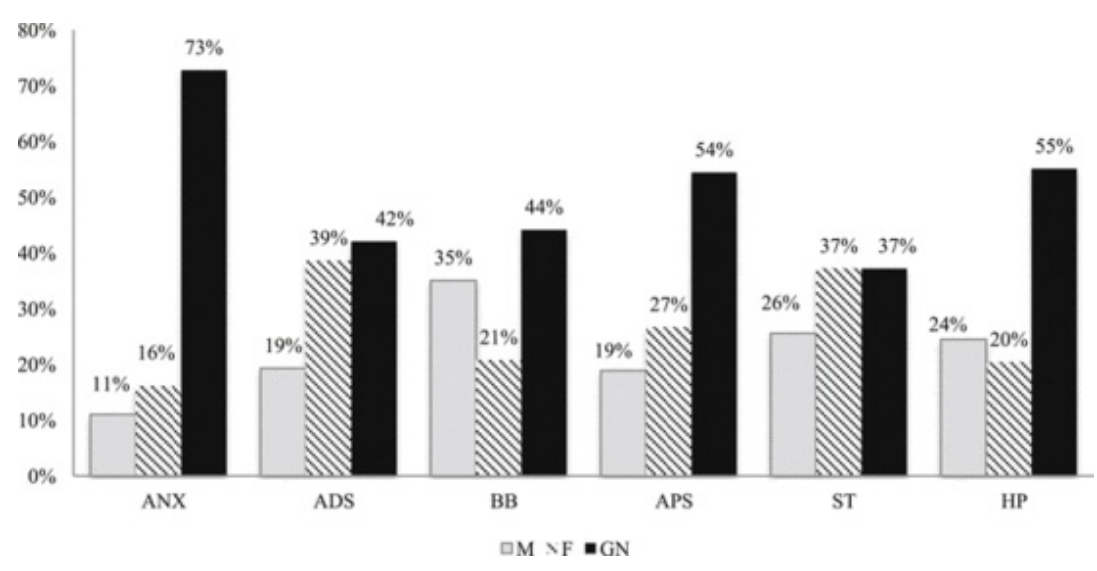




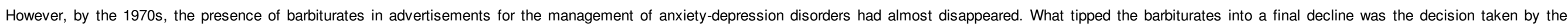

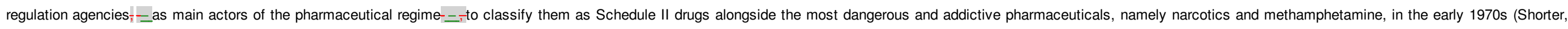
2008).

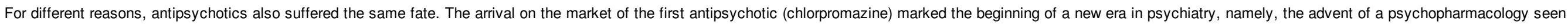

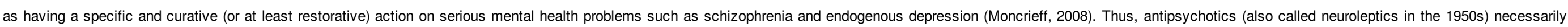

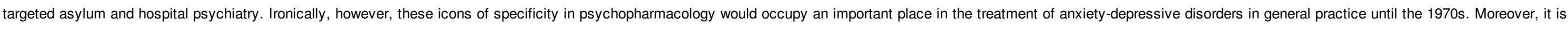

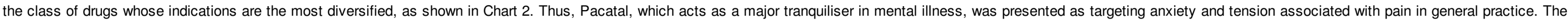

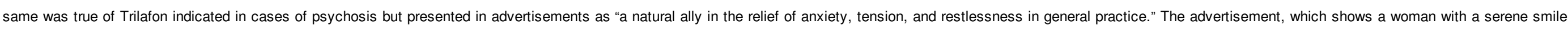

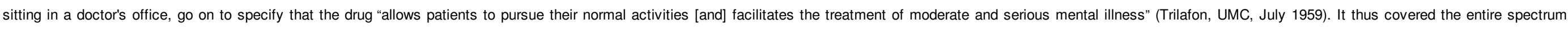

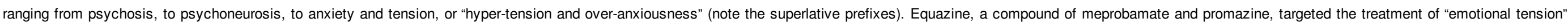
and "excessive worry" through a "dual action" that "combined the effect of two psychotropics on separate brain areas for a more specific treatment at low doses" (Equazine, UMC, March 1959).

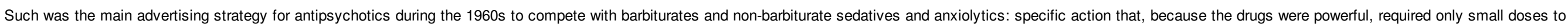

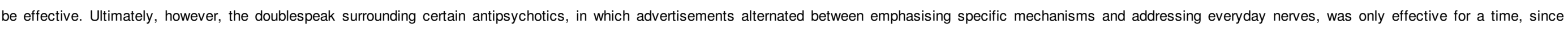
advertisements for antipsychotics would gradually disappear from general practice in the 1970s.

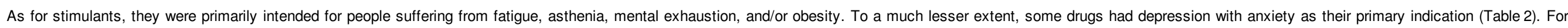

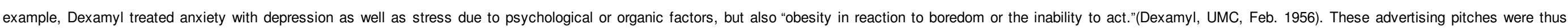

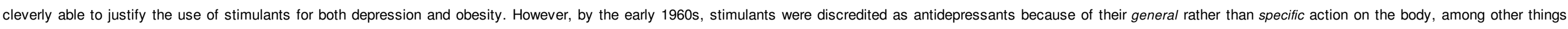

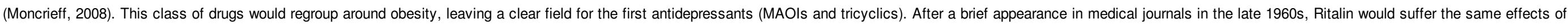

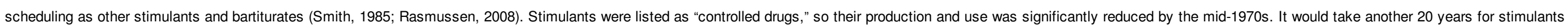
to make a comeback as a first-line treatment for ADHD (Conrad and Potter, 2000).

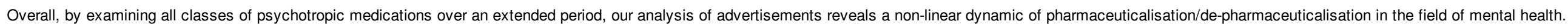

\section{The treatment of "everyday nerves " and the narrative of stress}

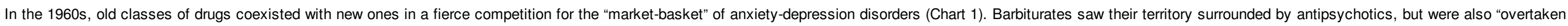
on the right" by non-barbiturate sedatives and anxiolytics, since psychosomatic disorders, emotional tension and anxiety would become their main indications (Chart 2).

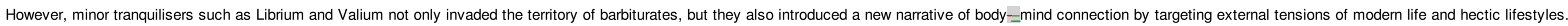

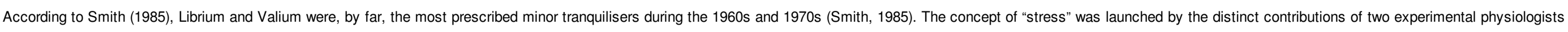

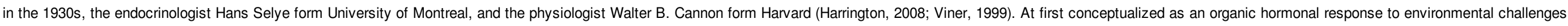

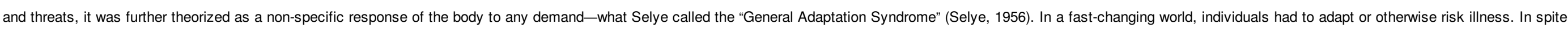

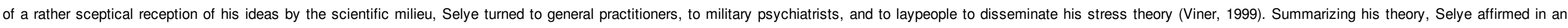

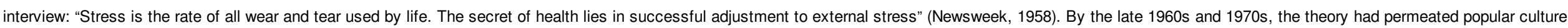

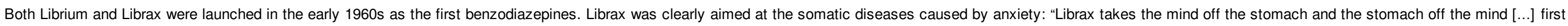

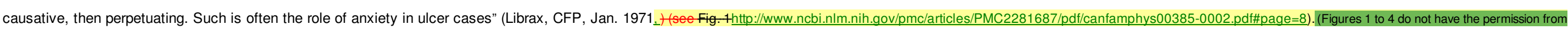

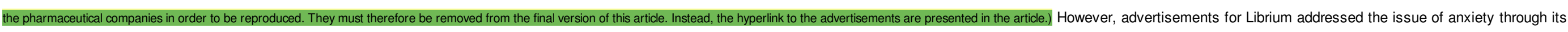

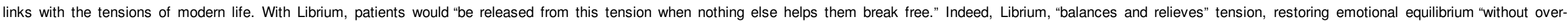


stimulating or over-calming" (Librium, UMC, March 1961).

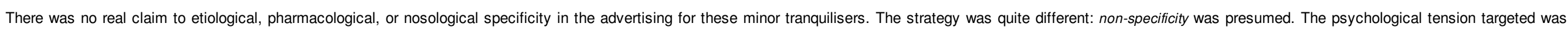

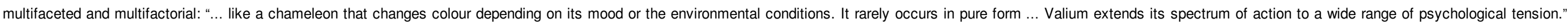
(Valium, UMC, May 1965)

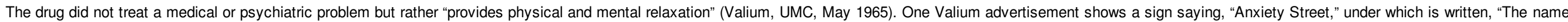

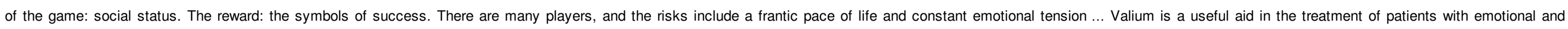

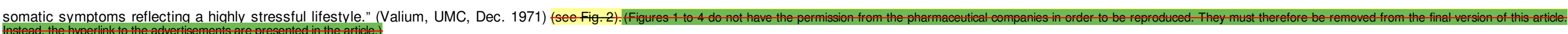

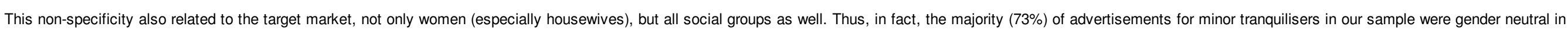

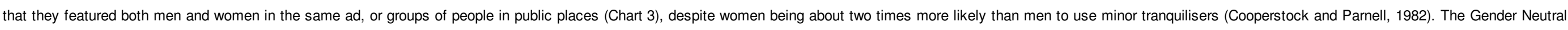

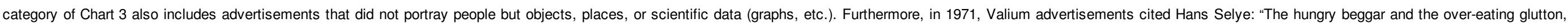

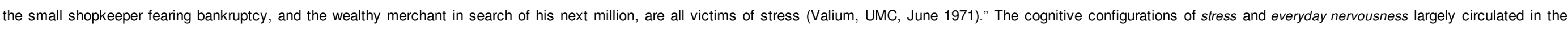
collective imagination are, in this instance, appropriated and exploited by the industry to expand its markets.

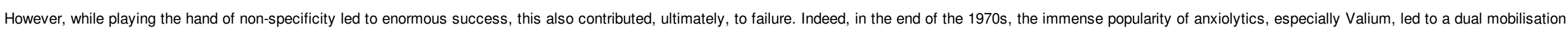

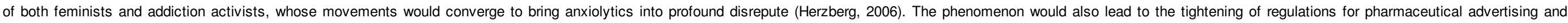
significant of pressure on prescribers to change their practices (Smith, 1985).

\section{The rise of "anxio-depressive syndrome"}

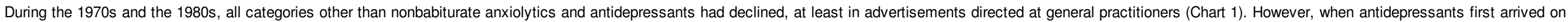

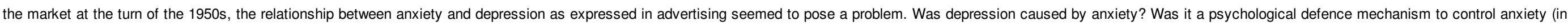
reference to the DSM-I)? Did it cause anxiety? Or did it form, with anxiety, a nebula whose outlines were blurred?

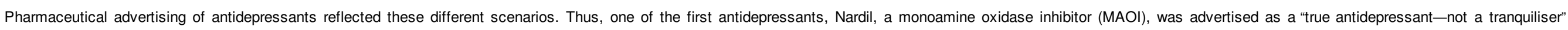

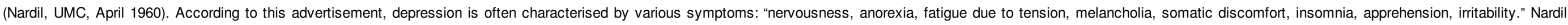

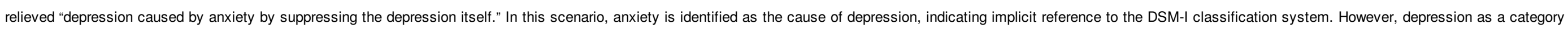
here refers to a generic term, an overall entity in which the boundary between psychosis and neurosis is not considered.

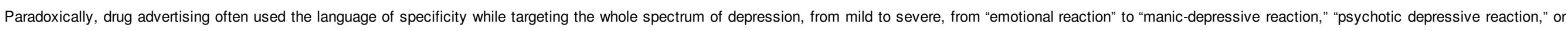

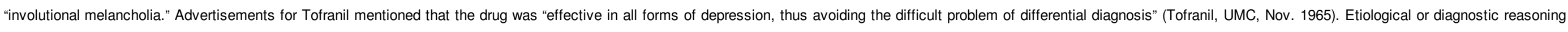
was no longer necessary: "Whatever the diagnosis ... when loss of health lead to depression in the elderly ... Tofranil $10 \mathrm{mg} . .$. will help restore hope, confidence and a desire for activity" (Tofranil, UMC, Sept. 1969).

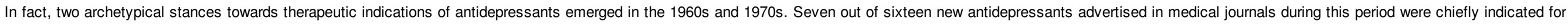

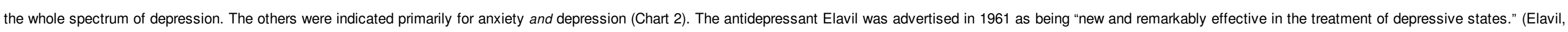

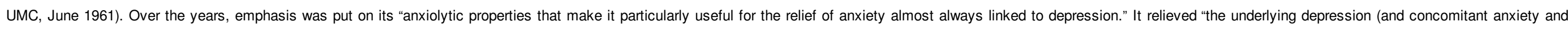
tension)" and was "an effective therapeutic agent against depression when accompanied by anxiety and unexplainable symptoms" (Elavil, UMC, Dec 1965).

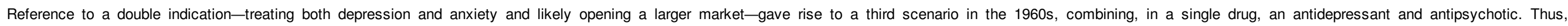

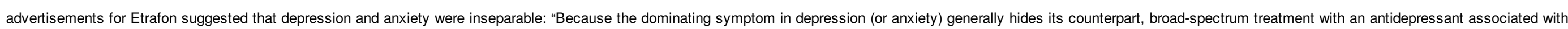

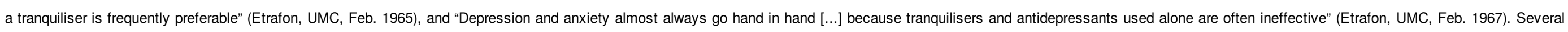
other drugs combining an antidepressant and an antipsychotic (Parsellin, Elavil Plus) were also marketed during this period. 


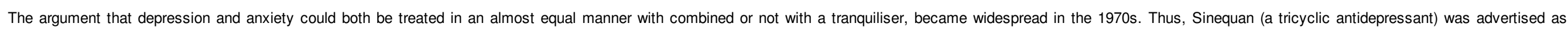

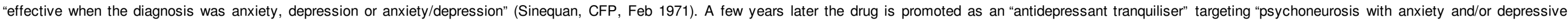
reactions," psychotic depression (including manic-depressive psychosis_-depressive type), and involutional melancholia (Sinequan, UMC, Feb. 1974).

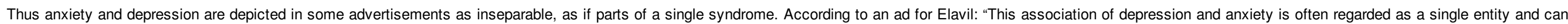

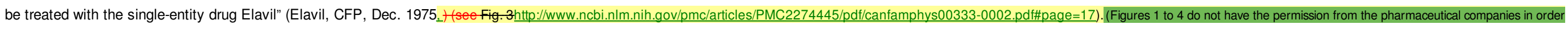
to be reproduced. They must therefore be removed from the final version of this article. Instead, the hyperlink to the advertisements are presented in the article.) The same strategy was used for Surmontil.

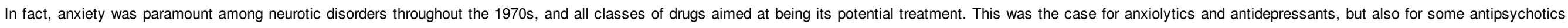

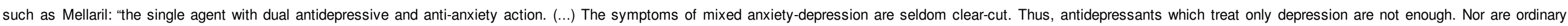
tranquilisers which treat the anxiety but not the depression" (Mellaril, CFP, Dec. 1970).

\section{DSM-III: the "brain as distinct from the individual" narrative}

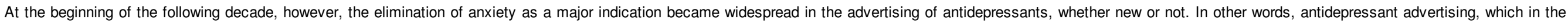
1970s emphasised effectiveness of the drugs in treating anxiety, refocused, in the 1980s, on their antidepressant indication (Chart 2).

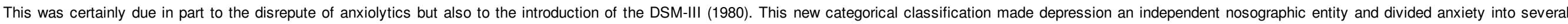

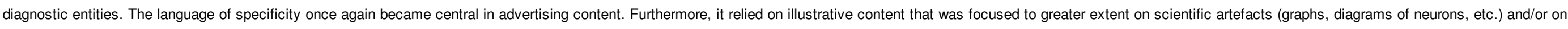

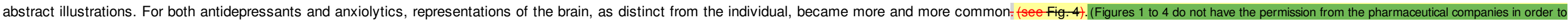

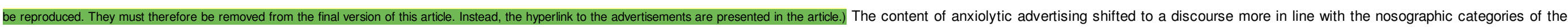

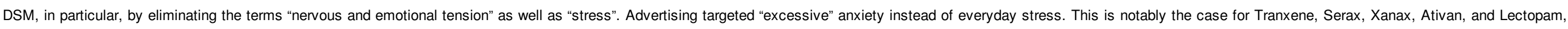
among others.

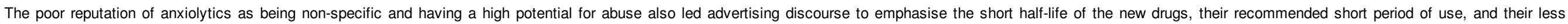

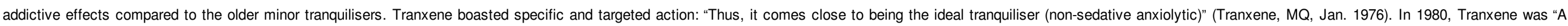

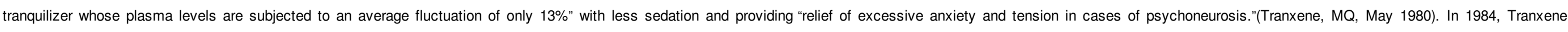

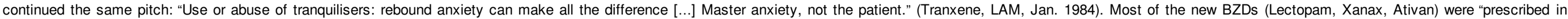
specific cases and for specific durations" (Lectopam, MQ, Feb. 1982).

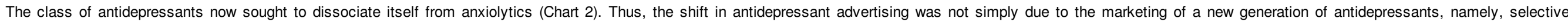

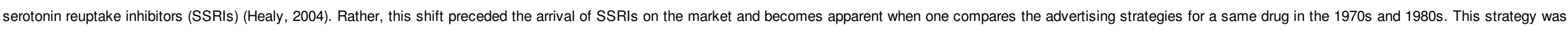

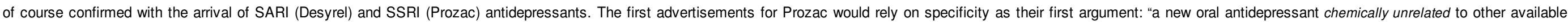

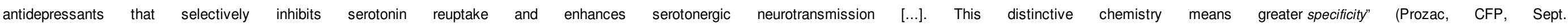

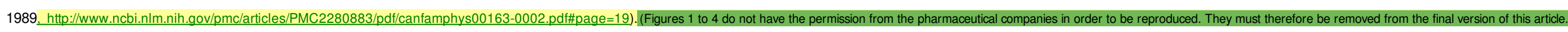

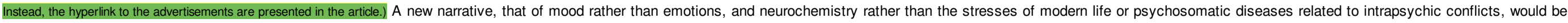
widely used in the following decades and would permeate popular culture (Montagne, 2001).

The rest is well-known history: a radical shift in the popularity of antidepressants as the new "wonder drugs" in the treatment of "everyday woes."

\section{Conclusion}

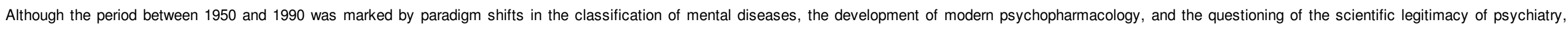
advertisements unveil a remarkable continuity: that of the mass management of anxiety-depressive disorders by primary care physicians through psychotropic drugs. 


\section{elsevier_SSM_9854}

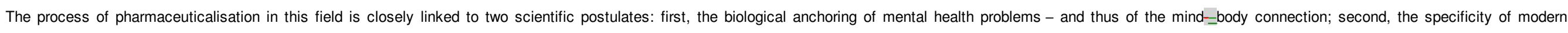
psychiatric drug treatments. Our analysis of advertisements shows the pervasiveness of these two assertions within the cognitive configurations structuring the advertising discourse directed toward general practitioners.

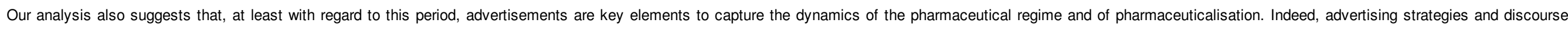

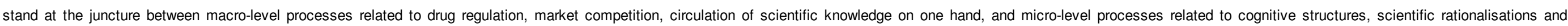

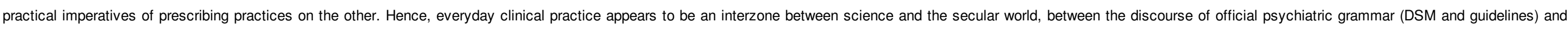
strong and ambiguous social demand, where therapeutic choices are necessarily influenced by the pharmaceutical industry.

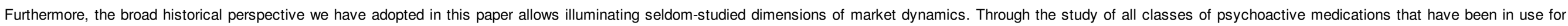

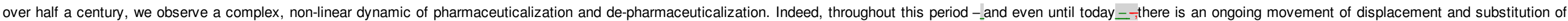

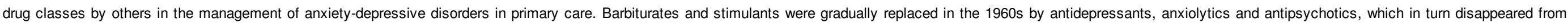

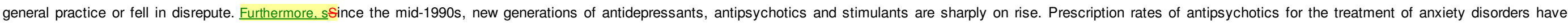
roughly doubled in the last two decades and despite a pervasive claim to specificity, the tendency to prescribe several drugs of the same class simultaneously has also risen (Olfson et al., 2012; Collin, 2014).

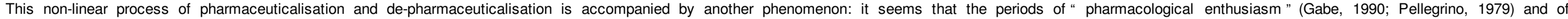

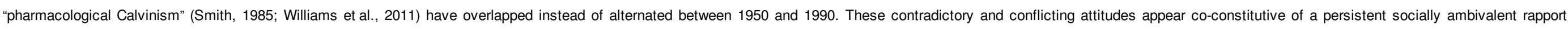
toward psychoactive substances in Western societies.

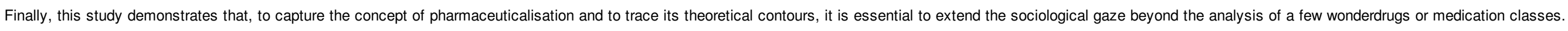

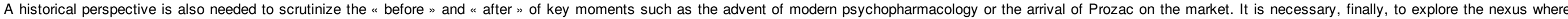
macro and micro regulations of medications and their uses converge.

\section{Uncited references}

American Psychiatric Association, 1968, American Psychiatric Association, 1980, Raison, 1969.

\section{Acknowledgement}

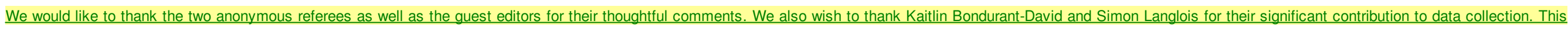
study was This supported by the Canadian Institutes of Health Research (CIHR) [no 115165 2011-2014].

\section{References}

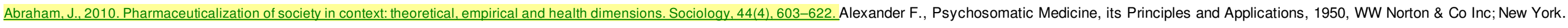

American Psychiatric Association, Diagnostic and Statistical Manual of Mental Disorders (DSM-I), 1952, Amercian Psychiatric Association Mental Hospital Service; Washington.

American Psychiatric Association, DSM-II, 1968, Amercian Psychiatric Association; Washington.

American Psychiatric Association, DSM-III, 1980, Amercian Psychiatric; Washington.

Braslow J.T., Mental Ills and Bodily Cures: Psychiatric Treatment in the First Half of the Twentieth Century, 1997, Univ of California Press; Berkeley and Los Angeles.

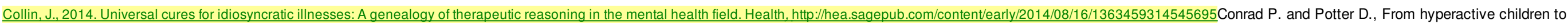

ADHD adults: observations on the expansion of medical categories, Soc. Probl. 2000, 559-582.

Cooperstock R. and Parnell P., Research on psychotropic drug use: a review of findings and methods, Soc. Sci. Med. 16, 1982, $1179-1196$.

Ettorre E., Klaukka T. and Riska E., Psychotropic drugs: long-term use, dependency and the gender factor, Soc. Sci. Med. 39 (12), 1994, 1667-1673. 


\section{elsevier_SSM_9854}

Fortin D., Diagnostic differential et conduit thérapeutique, Union Méd. Can. 94 (2), 1965, 196-210.

Gabe J., Towards a sociology of tranquillizer prescribing, Br. J. Addict. 85, 1990, 41-48.

Harrington A., The Cure Within: a History of Mind-Body Medicine, 2008, W. W. Norton \& Company.

Healy D., The Creation of Psychopharmacology, 2002, Harvard University Press.

Healy D., Shaping the intimate: influences on the experience of everyday nerves, Soc. Stud. Sci. 34 (2), 2004, 219-245.

Herzberg D., "The pill you love can turn on you": feminism, tranquilizers, and the Valium Panic of the 1970s, Am. Q. 58, 2006, 79-103.

Herzberg D., Happy Pills in America: From Miltown to Prozac, 2009, JHU Press.

Horwitz A.V., How an age of anxiety became an age of depression, Milbank Q. 88 (1), 2010, 112-138.

Klein D.F. and Davis J.M., Diagnosis and Drug Treatment of Psychiatric Disorders, 1969, Williams \& Wilkins; Baltimore.

Metzl J., Prozac on the Couch: Prescribing Gender in the Era of Wonder Drugs, 2003, Duke University Press.

Moncrieff J., The Myth of the Chemical Cure: a Critique of Psychiatric Drug Treatment, 2008, Palgrave Macmillan.

Montagne M., Mass media representations as drug information for patients: the prozac phenomenon, Subst. Use Misuse 36, 2001, 1261-1274.

Newsweek, Toward Sounder Hearts: Interview with H. Selye. March 31, C4 219, 1958

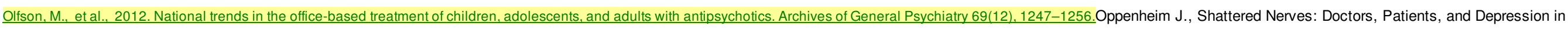
Victorian England, 2001, Replica Books.

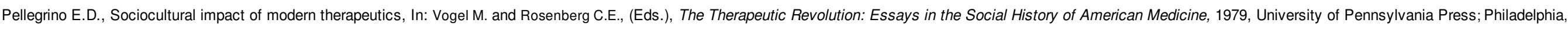
245-268.

Raison Arnold V., A Brief History of Pharmacy in Canada, 1969, Canadian Pharmaceutical Association; Toronto.

Rasmussen N., On Speed: the Many Lives of Amphetamine, 2008, NYU Press; New York and London.

Rosenberg. C.E., 2007. Our Present Complaint. American Medicine Then and Now. The Johns Hopkins University Press. Baltimore.Selye H., The Stress of Life, 1956, McGraw Hill Co; New York.

Shorter E., Before Prozac: the Troubled History of Mood Disorders in Psychiatry: the Troubled History of Mood Disorders in Psychiatry, 2009, Oxford University Press.

Smith M.C., Small Comfort. A History of the Minor Tranquilizers, 1985, Preager; New York.

Tone A., The Age of Anxiety: a History of America's Turbulent Affair with Tranquilizers, 2009, Basic Books.

Viner R., Putting stress in life Hans Selye and the making of stress theory, Soc. Stud. Sci. 29 (3), 1999, 391-410.

Whooley O. and Horwitz A.V., The paradox of professional success: grand ambition, furious resistance, and the derailment of the DSM-5 revision process, In: Making the DSM-5, 2013, Springer, 75-92.

Williams S.J., Martin P. and Gabe J., The pharmaceuticalisation of society? A framework for analysis, Sociol. Health IIIn. 33 (5), 2011, 710-725. 


\section{elsevier_SSM_9854}

- This is a comprehensive analyses of drug advertising in general medical journals.

- It provides a picture of the pharmacological landscape between 1950 and 1990.

- All classes of psychotropic drugs were advertised for mild mental disorders.

\section{Queries and Answers}

Query: Please note that as per journal style author role has not been retained in the affiliations. Kindly check and amend if necessary.

Answer: Done

Query: Please check the affiliation "a and b". Kindly correct if necessary.

Answer: It is done

Query: Please check the corresponding author field and correct if necessary.

Answer: It is done

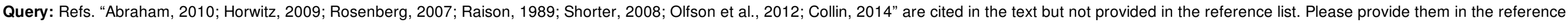
list or delete these citations from the text.

Answer: I provided them in the reference list.

Query: Please check the hierarchy of the headings and sub-headings.

Answer: I checked. Everything is okay now.

Query: Please check the layout of "Tables 1 and 2".

Answer: I checked table 1 and 2 and I made the necessary corrections in table 1.

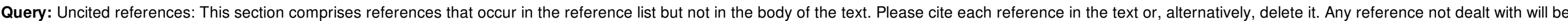
retained in this section.

Answer: Each reference is now cited in the text.

Query: Please confirm that given names and surnames have been identified correctly.

Answer: I confirm that given names and surnames have been identified correctly.

Query: For figure 2, the resolution is too low to be used. Please provide better quality figure of $300 \mathrm{dpi}$.

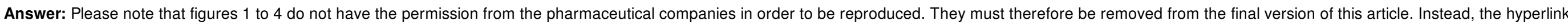
to the advertisements are presented in the article. 